
\title{
25 Research Sourere \\ Of Lemmings and Mussels: Trophic Cascade Drives Population Dynamics of Long-Tailed Ducks Breeding in Siberia
}

\section{Jukka Rintala}

Devecto Oy

\section{Hario}

Natural Resources Institute Finland

K. Laursen

Aarhus University

A. P. Møller ( $\square$ anders.moller@universite-paris-saclay.fr ) Université Paris-Sud, CNRS, Université Paris-Saclay

\section{Research Article}

Keywords: Bayesian analysis, bottom-death, density dependence, dissolved nitrogen, phosphorus, statespace model, temperature, variance partition, Wadden Sea

Posted Date: January 5th, 2022

DOI: https://doi.org/10.21203/rs.3.rs-1206081/v1

License: (c) (i) This work is licensed under a Creative Commons Attribution 4.0 International License. Read Full License 


\section{Abstract}

Migratory animals experience very different environmental conditions at different times of the year, i.e., at the breeding grounds, during migration, and in winter. The long-tailed duck Clangula hyemalis breeds in the Arctic regions of the northern hemisphere and migrates to temperate climate zones, where it winters in marine environments. The breeding success of the long-tailed duck is affected by the abundances of predators (mainly Arctic fox Alopex lagopus) and their main prey species, lemmings Lemmus sibiricus and Dicrostonyx torquatus, whose population fluctuation is subject to climate change. In the winter quarters, long-tailed ducks mainly eat the blue mussel Mytilus edulis. We examined how North-west Siberian lemming dynamics affect long-tailed duck breeding success via predation pressure and how nutrient availability in the Baltic Sea influences long-tailed duck population size via mussel biomass and quality. The long-tailed duck population dynamics was predator-driven on the breeding grounds and resource-driven on the wintering grounds. Nutrients from fertilizer runoff from farmland stimulate mussel stocks and quality, supporting high long-tailed duck population sizes. The applied hierarchical analysis combining several trophic levels can be used for evaluating large-scale environmental factors that affect the population dynamics and abundance of migrants from one environment to another.

\section{Introduction}

Migratory organisms spend part of the year at the breeding grounds before moving to winter quarters that are often located thousands of kilometres away ${ }^{1}$. Changes in environmental conditions at the breeding grounds or winter quarters influence performance of migrants in the same or the other habitat ${ }^{2,3}$. The long-tailed duck Clangula hyemalis is globally threatened and classified as Vulnerable on the IUCN Red List. It winters in North Europe and migrates along the Gulf of Finland to and from the breeding areas in Western Siberia ${ }^{4}$. Spring migration counts at Söderskär, Finland in the 1940 s and 1950 s showed a $90 \%$ reduction of the long-tailed duck population in the Baltic Sea wintering area ${ }^{5,6}$. During the Second World War, oil spills were suggested to be the main reason for the decline ${ }^{5,7,8}$. The wintering population gradually recovered as environmental conditions improved, with over half a million migrants. Spring counts peaked during 1991-1996 in Finland ${ }^{8}$ and Estonia ${ }^{9}$, followed by severe declines during the 2000 s with recent numbers of migrants being only one-third of peak-year numbers (190,000 vs. 570,000 individuals). The North-west Siberian/North European winter population of the long-tailed duck was estimated at 4,700,000 birds based on co-ordinated surveys $1992-1993^{6,10}$, of those numbers the Baltic Sea winter population declined from $4,272,000$ to $1,482,000$ birds until $2009{ }^{6}$.

Population characteristics of many species of aquatic birds that breed in the Arctic covary with population cycles of Arctic lemmings (Lemmus sibiricus and Dicrostonyx torquatus). These rodents are important prey for Arctic foxes, skuas and raptors, and thus form an essential component of the Arctic ecosystem ${ }^{11}$. Vole and lemming populations exhibit cyclic dynamics, particularly in northern regions ${ }^{12}$, with population peaks occurring every 3-5 years ${ }^{13-15}$ often followed by almost total absence of individuals ${ }^{13,15-18}$. Years with high abundance of lemmings lead to an increase in predator populations 
that show cycles that track those of their rodent prey ${ }^{19-22}$ such that predators are abundant the year following a rodent peak year while their populations are low after such lemming years ${ }^{16,23}$. In the year following a rodent peak, when predator populations are high, these predators exploit alternative prey 8,24-28 such as bird eggs and young of species such as the long-tailed duck $26,29,30$, leading to large-scale breeding failure in these birds $26,31,32$ and fewer juveniles recruiting into the winter population $8,15,33$.

North-west Siberian/North European long-tailed ducks have declined since the $1990 \mathrm{~s}^{6}$, coinciding with reductions in lemming abundances throughout the Arctic and northern alpine areas ${ }^{34-36}$ that has been linked to global climate warming, which particularly affects the Arctic. Indeed, changes in snow conditions due to climate change may explain why lemming populations show fewer peaks ${ }^{37}$. Snow hardness and humidity in the High Arctic, influenced by changing weather conditions, are critical for winter survival and reproduction in lemmings ${ }^{37-39}$.

The blue mussel, Mytilus edulis, constitutes the main food item for long-tailed ducks during winter ${ }^{40-42}$. Wintering success of long-tailed ducks declines with declining stocks of blue mussels Mytilus edulis in the southern Baltic Sea ${ }^{43}$. Mussel abundance is affected by climate, with cold winter temperatures stimulating reproduction in blue mussels, which may increase mussel stock sizes and thus sea duck populations a few years later ${ }^{44}$. Mussel abundance is also affected by fertiliser runoff in two ways. Fertilizer runoff from farmland increases dissolved nutrient levels, which increases primary production in the Baltic Sea 45,46 and stimulates a bottom-up trophic cascade in coastal areas $44,47,48$. However, this also causes hypoxia and bottom death, which reduces abundance and availability of mussels in large areas of the Baltic Sea where there is poor mixing or influx of fresh, oxygenated water ${ }^{45}$ and where longtailed ducks spend the winter.

Here we identify and quantify the ecological processes and their contributing environmental factors that influence the population dynamics of long-tailed ducks during both breeding and winter. For processes occurring at the breeding grounds, we tested how predation risk, estimated from lemming abundances in the previous year, and variability in precipitation and temperature in North-western Siberia influenced the proportion of juveniles at the wintering grounds in the southern Baltic Sea. For the processes occurring at the wintering grounds we analysed how nutrient amounts, in the form of dissolved nitrogen and phosphorus, and winter climate influenced long-tailed duck juvenile proportions and spring migration population size. Using a hierarchical Bayesian ${ }^{49,50}$ model, implemented with the above listed environmental variables, we show how lemming dynamics affected the proportion of juveniles in autumn and winter and how these together with nutrient availability explained spring migration numbers of the long-tailed duck the following spring. This study exemplifies how to analyse complex dynamical systems based on heterogeneous and partly incomplete time-series data.

\section{Materials And Methods}

Ethics declaration 
This article does not contain any experiments on animal subjects performed by any of the authors.

\section{Observations of long-tailed ducks}

Spring migration counts of long-tailed ducks have taken place at Söderskär ( $\left.60^{\circ} 07^{\prime} \mathrm{N}, 25^{\circ} 24^{\prime} \mathrm{E}, \mathrm{Fig} .1\right)$, Gulf of Finland each spring 1968 - 2014. These counts are generally assumed to reflect population size 8 , and there is no indication that the main migration corridor for Baltic long-tailed ducks has changed during the study. However, wind direction and velocity at Söderskär can force migrating birds off their preferred migration route ${ }^{51,52}$, thereby causing variation in migrant bird counts. To control for this error source, we used daily wind direction and velocity measures at Söderskär during spring migration counts. We developed a weighted wind direction and velocity factor to be implemented into the observation model of the long-tailed duck to correct long-tailed duck population size estimates by reducing noise due to the effect of wind on spring migration counts ${ }^{53,54}$ (details in Supplementary Methods).

We estimated recruitment from the number of juvenile ( $1 \mathrm{st}$ to 2 nd calendar year individuals) in relation to the number of adult female birds shot by hunters in autumn and winter (juvenile proportion in year $t$ refers to bags from October in year $t$ until February in year $t+1$ ) from the Danish Wing Survey data ${ }^{55,56}$ and related this to lemming abundance (of the year $t-1$ ) in North-western Siberia during breeding and climate conditions in breeding and wintering grounds (Supplementary Methods).

\section{Environmental variables}

(1) Nutrient levels. Dissolved inorganic nitrogen (DIN), considering the sum of the oxidized nitrogen and ammonium pool, and phosphorus (DIP) have been estimated for the Baltic Sea major basins each year from 1970 to $2016^{46}$. We tested the effects of total DIN and DIP recorded from the southern Baltic Sea, the Baltic Proper and the Danish Straits major basins ${ }^{46}$ (Fig. 1), covering the main wintering area of the long-tailed duck, on the population dynamics of this species. Nutrient effects can be positive, because additional DIN stimulates primary production and thereby growth of mussels, the primary food of this species during winter ${ }^{40-42}$, or negative, because of hypoxia and bottom death that can occur at low DIN:DIP ratios ${ }^{46}$ in areas of poor mixing ${ }^{45}$. We used the total annual amount of fertilizer applied by Danish farmers during 1965-2016 as a predictor of marine nutrient pools in the southern Baltic Sea because this variable is a reliable proxy for total nitrogen runoff into the marine environment ${ }^{47}$ (see Supplementary Methods).

(2) Lemming abundances. The majority of long-tailed ducks wintering in the Baltic Sea originate from the part of North-western Siberia including the Yamal and Taimyr Peninsulas ${ }^{57}$. Lemming abundance across the entire breeding area should influence the dynamics of the long-tailed duck population, but such data are lacking. However, information on lemming abundance exists from three separate, long-termed surveys in the Western Taimyr Peninsula, North-western Siberia, which allow us to quantify regional population changes in lemmings (Fig. 1). One survey was performed within a zone of ca. $100 \mathrm{~km}$ along the coast of the Kara Sea, Western Taimyr, between 80 and $90^{\circ} \mathrm{E}^{14,15}$ and two other surveys took place on the Western 
Taimyr Peninsula ${ }^{13}$ (survey no. 44, Meduza Bay, $73^{\circ} 04^{\prime} \mathrm{N}, 80^{\circ} 30^{\prime} \mathrm{E}$; and survey no. 45, Mys Vostochnyi, $74^{\circ} 06^{\prime} \mathrm{N}, 86^{\circ} 48^{\prime} \mathrm{E}$ ) (see Supplementary Methods).

(3) North-west Siberian climate. We extracted annual (1965-2017) monthly climatological variables (precipitation and temperature) from a database of high spatial resolution global weather and climate data ${ }^{58,59}$ (data downloaded from www.worldclim.org) for the three regions in Western Taimyr for which lemming abundance data were available. Climate variation was averaged for the three areas corresponding to the three rodent surveys (Fig. 1). We tested if climate variability affected rodent population sizes ${ }^{37}$, which may influence the breeding success and population dynamics of the longtailed duck ${ }^{8}$. Similarly, for estimating climate effects on recruitment, we averaged annual precipitation and temperature scores for North-western Siberia (Fig. 1). For processing the climatological map data, we used the $R$ package 'raster' 60 .

(4) North Atlantic Oscillation Index (NAOI). Winter NAOI (December in year $t-1$ until February in year $t$ ) is an index of the severity of winter conditions in the Northern Atlantic ${ }^{61,62}$. High index values indicate high winter temperatures and high levels of precipitation in the Baltic Sea ${ }^{61}$. NAOI data were obtained from https://climatedataguide.ucar.edu/climate-data/hurrell-north-atlantic-oscillation-nao-index-pc-based. We estimated the effects of winter NAOI on the proportion of juveniles killed by Danish hunters and on population dynamics of long-tailed ducks.

(5) Abundance and quality of blue mussels. Long-tailed ducks feed on blue mussels. Though no longterm data exist for mussel stocks in the Baltic Sea, such data are available from the Wadden Sea although this is outside the core winter grounds of the long-tailed duck ${ }^{6}$. Two arguments justify the use of mussel stock data from the Wadden Sea as a proxy for the missing mussel stock data from the Baltic: First, population trends of mussel stocks are comparable over areas covering several hundred kilometres ${ }^{63}$, and, second, the eider Somateria mollissima, another sea duck, also feeds primarily on blue mussels and winters in the Baltic Sea. Winter body condition of eiders in the Baltic is positively correlated with mussel stock estimates for the Wadden Sea ${ }^{64,65}$.

In the Baltic Sea, in the western part of the Finnish Archipelago, blue mussels grow from larvae to $10 \mathrm{~mm}$ within 3-4 years ${ }^{66}$ so we expect mussels in the southern Baltic Sea ecosystem to attain the size of 9 $\mathrm{mm}$ preferred by long-tailed ducks ${ }^{43}$ in about the same period after spawning. Annual blue mussel stocks were estimated for the intertidal zone of the Danish (1986-2007, and 2017) and SchleswigHolstein (Germany, 1998-2015) parts of the Wadden Sea (Fig. 1) during autumn by ground sampling on mussel beds and estimation of mussel beds from aerial photography ${ }^{67,68}$. Mussel stock data are available for both areas from 1998-2007 and annual biomass showed a positive correlation between the areas $(r=0.920, N=10)$.

Data were available for blue mussel quality, measured as flesh to shell ratio ${ }^{69}$, each autumn from 1998 to 2013 from 19 sites in the Baltic and Wadden Sea. The reduction in mussel flesh content during winter 
(October-March) due to temperature-dependent respiration was estimated for the Baltic Sea ${ }^{70}$. This allowed us to estimate long-tailed duck food resources by predicting mussel numbers and quality as a function of the amount of fertilizer applied by Danish farmers (see Supplementary Methods) and winter and spring temperatures along the Wadden Sea coastline, using the same global climate database as described above (see "North-west Siberian climate").

\section{Hierarchical modelling}

We used an integrated hierarchical model ${ }^{71}$, which is a complex stochastic system partitioned into a dependent sequential set of simpler sub-models dynamically affecting the performance of the main system of interest ${ }^{71}$. In the following system, the state-space model, equation (1), expressing log-scale long-tailed duck dynamics (1968-2014) is written briefly as:

$$
\begin{gathered}
\hat{n}_{(t)}=a+c n_{(t-1)}+\beta_{R} \log R_{(t-1)}+ \\
\beta_{D}\left[\left(1-w_{D}\right) D I N_{(t-1)}+w_{D}\left(-1 * D I P_{(t-1)}\right)\right]+\epsilon_{(t)}
\end{gathered}
$$

1

in which $n_{(t)}$ is the population size estimate of long-tailed ducks in year $t$ that has a negative binomial error structure 49,72 around the expected population size $\hat{n}_{(t)} \cdot R_{(t-1)}=1+p_{(t-1)}$ is a variable for recruitment based on estimated juvenile proportion $\left(p_{(t-1)}\right)$, from equation (2), in autumn and winter preceding spring migration. Terms $a$ and $\epsilon_{(t)}$ are intrinsic growth rate (intercept) and random environmental disturbance terms, respectively. cis a density-dependent parameter whose value can vary from zero to one. Dissolved nitrogen $D I N_{(t-1)}$ and phosphorus $D I P_{(t-1)}$ describe annual nutrient pools in the southern Baltic Sea (outputs from equation (4a)). The nutrient series implemented into equation (1) were scaled to have a mean of zero and variance of one. $w_{D}$ weights nutrient effects and $\beta_{R}$ quantifies the effect of juvenile proportion in autumn and winter on subsequent spring migration counts; these parameters are beta distributed varying between zero and one (uninformative prior beta-distribution with $\alpha=1$ and $\beta=1$ ). $\beta_{D}$ is normally distributed regression coefficient. The observation model for equation (1) is specified with Gaussian errors and a priori assumed environmental disturbances (wind) as:

$$
y_{(t)} \mid n_{(t)} \sim \operatorname{normal}\left(n_{(t)}+\gamma x_{(t)}, \tau^{2}\right),
$$

and $\tau$ is the standard deviation of a random observation-error process (Supplementary Methods). The joint-likelihood ${ }^{71}$ of the integrated hierarchical model combining equations (1), (2) and (3) is summarized with Supplementary Table S1.

We constructed a logit model to generalize the variations of juvenile proportions during the period 19672017 , based on the number of juveniles per adult female shot by Danish hunters:

$$
\operatorname{logit} p_{(t)}=a_{p}+b_{L} Z_{(t-1,1)}+b_{C} C_{(t-3)}+\sum_{k=1}^{2} b_{(S, p) k} S_{(t, k)}+r_{p(t)}
$$


Here, $p_{(t)}$ is the expected proportion of juveniles (in autumn and winter) affecting subsequent spring migration numbers (population size $n_{(t+1)}$, equation (1)) of long-tailed ducks. $z_{(t-1, j=1)}$ is an estimate for (log) lemming population size in the previous year based on the longest series of lemmings (Kara Sea, $j=1$ ) from equation (3). $C_{(t-3)}$ is a variable for winter climate (NAOI ${ }_{\mathrm{Dec}-\mathrm{Feb}}$ ) three years before. $b_{(S, p) k S_{(t, k)}}$ terms quantify the effects of precipitation $(k=1)$ and temperature $(k=2)$ in North-western Siberia in May and June on juvenile proportions, and these were weighted, e.g. for precipitation $(P)$, as $S_{t, 1}=w_{\text {June, } 1}\left(1-P_{\text {May }}\right)+w_{\text {June, } 1} P_{\text {June }} \cdot a_{p}$ and $b_{X}$ are estimated regression coefficients, and $r_{p(t)}$ controls for random effects (full description in Supplementary Methods).

Lemming population dynamics $Z_{(}(t, j)$ estimated using three separate population time-series $(j)$ of lemming abundances in the Western Taimyr Peninsula (1965-2017, $t=0$ refers to 1965) was estimated based on the following state-space model:

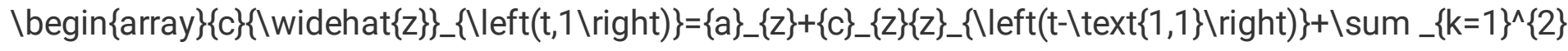
$\{b\}_{-}\{\backslash$ left(C\right) $k\}\{C\}_{-}\{\backslash$ left $(t, k, 1 \backslash$ right $)\}+\{\{X\}\}_{-}\{1\} a+\{\{X\}\}_{-}\{2\} b+\{b\}_{-}\{t\} \backslash$ left(t-1 $\backslash$ right $)+$ $\{\epsilon\}_{-}\{z \backslash$ left $(\mathrm{t}, 1 \backslash$ right $)\} \backslash \backslash\{\text { widehat }\{z\}\}_{-}\{\backslash \operatorname{left}(\mathrm{t}, \mathrm{j}=2 \mid \mathrm{j}=3 \backslash$ right $)\}=\{\backslash \text { widehat }\{\mathrm{z}\}\}_{-}\{\backslash$ left $(\mathrm{t}, 1 \backslash$ right $)\}+\{\backslash$ delta

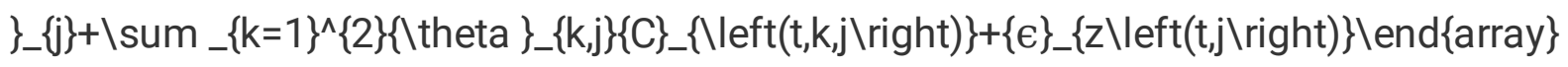
3

in which the error in lemming population size estimates $\{z\}_{-}\{\backslash$ left(t,j $\backslash$ right $\left.)\right\}$ following a negative binomial around the expectation $\{\backslash \text { widehat }\{z\}\}_{\_}\left\{\backslash\right.$ left(t, $\backslash \backslash$ right)\} (detailed in Supplementary Methods). $\{a\}_{-}\{z\}$ levels population $\mathrm{j}=1$, and additive scaling parameters for populations 2 and 3 are denoted by $\{\backslash \text { delta }\}_{-}\{2\}$ and $\{\backslash \text { delta }\}_{-}\{3\}$ ( $\left.\{\backslash \text { delta }\}_{-}\{1\}=0\right)$; similarly, $\{b\}_{-}\left\{\backslash\right.$ left(C\right)k\} adjusts climate $\left(\{C\}_{-}\{(\backslash\right.$ left $(t, k, j \backslash r i g h t)\})$ effects for population $\mathrm{j}=1$, and scaling (additive to population 1 ) for populations 2 and 3 are denoted by $\{\backslash$ theta \}$_{-}\{k, 2\}$ and $\{\backslash \text { theta }\}_{-}\{k, 3\}$ ( $\left.\{\backslash \text { theta }\}_{-}\{k, 1\}=0\right)$. Subscript $k$ indicates precipitation in summer $\backslash$ left $(t, k=1 \backslash$ right $)$ and the previous autumn $\backslash$ left $(t-1, k=2 \backslash$ right $)$ for each population $j_{\text {. }}\{b\}_{-}\{t\}$ is a parameter for a temporal trend effect. $\{\epsilon\} \_\{z \backslash \text { left(t,j\right)\} controls for random environmental disturbances. Parameter vectors }\{a\}$ and $\{b\}$ measure the consistency in three-year cyclic dynamics designed to dummy variable $(0,1)$ matrices $\{\{X\}\}_{-}\{1\}(1965-1994)$ and $\{\{X\}\}_{-}\{2\}$, (1995-2017) in which ones enable regular effects by threeyear intervals (details in Supplementary Methods).

A log scale state-space model for fertilizer \left(\{F\}_\{t\}\right) effect on nutrient pools measured in the Danish Straits $\backslash$ left $(j=1 \backslash$ right) and the Baltic Proper $\backslash$ left $(j=2 \backslash$ right $)$, returning state estimates $\{D\}_{-}\{($left $(t, k \backslash$ right $)\}$ for DIN \left(k=1\right)and DIP \left(k=2\right) for the southern Baltic Sea in 19702016:

$\backslash$ begin $\{$ array $\}\{c\}\{D\}_{-}\{\backslash$ left $(t, k \backslash$ right $)\}=\{a\}_{-}\{k\}+\{c\}_{-}\{k\}\{D\}_{-}\{\backslash$ left $(t-1, k \backslash$ right $)\}+\left\{\{b\}_{-}\{k\} F\right\}_{-}\{\backslash$ left $(t-l a g \backslash$ right $)\}+$ $\{\backslash \text { text }\{s\} \backslash \text { eft(F\right) }\}_{-}\{t-l a g, k\}+\{e\}_{-}\{\backslash$ eft $(t, k \backslash$ right $)\} \backslash$ end $\{$ array $\}$ 


$$
D_{\mathrm{obs}(t, j, k)} \sim \operatorname{normal}\left(D_{(t, k)}+a_{j, k}, s_{D(j, k)}^{2}\right)
$$

where $\{a\}_{-}\{k\}$ parameters are intercepts for DIN and DIP, and $\{c\}_{-}\{k\}$ controls for serial correlation. $\{b\}_{-}\{k\}$ is a parameter for fertilizer-use effect on the nutrient pools. Non-linear effects are specified with a spline function for fertilizers generating two additive smoothing variables ${ }^{73}$ : $\{\backslash \operatorname{text}\{s\} \backslash \text { left(F\right) }\}_{-}\{t, k\}$

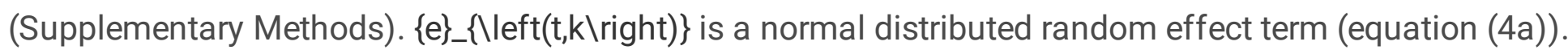
Observed nutrient amounts link to the states via an observation model, equation (4b), with intercepts $\{a\}_{-}\{j, k\}$ and standard deviation $\{s\}_{-}\{D \backslash$ left(j,k\right)\}. The lag parameter is binomially distributed and can have values of $0,1,2$ or 3 (years) (Supplementary Methods).

To estimate how biomass of mussels, the main food items for long-tailed ducks, increases with increasing nutrient availability, we built a model based on two mussel biomass surveys of the Wadden Sea, assuming that temperature and nutrients have comparable effects on mussel population growth in the Wadden Sea and the southern Baltic Sea (Supplementary Methods). These effects exclude hypoxia due to nutrient overflow because this does not occur in the strongly tidal well-mixed Wadden Sea, though it does in the Baltic Sea. Thus, a state-space model for mussel (log) biomasses in The Danish Wadden Sea $(j=1)$ for the period $1986-1997$ is expressed as:

$\{\backslash \mathrm{mu}\}_{-}\{\backslash$ left $(\mathrm{t}, \mathrm{j}=1 \backslash$ right $)\}=\{\mathrm{a}\}_{-}\{\backslash \mathrm{mu}\}+\{c\}_{-}\{\mathrm{mu}\}\{\backslash \mathrm{mu}\}_{-}\{\backslash \operatorname{left}(\mathrm{t}-\backslash \operatorname{text}\{1,1\} \backslash \operatorname{right})\}+\left\{\{\mathrm{b}\}_{-}\{F\} F\right\}_{-}\{\backslash$ left $(\mathrm{t}-$

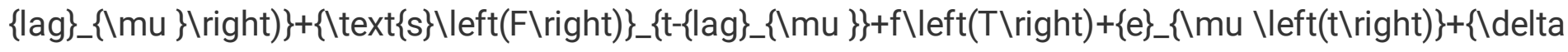
\}$_{-}\{\backslash \mathrm{mu} \backslash$ left(t, $1 \backslash$ right $\left.)\right\}$

5

where $\{a\}_{-}\{\backslash m u\}$ is intercept and $\{c\}_{-}\{\backslash m u\}$ is a density dependent parameter. $\{e\}_{-}\{\backslash m u \backslash$ left $(t \backslash r i g h t)\}$ controls for state-process errors due to environmental variance and $\{\backslash \text { delta }\}_{-}\{(\mathrm{mu} \backslash$ left(t,1\right)\} for demographic variance ${ }^{74,75}$. A function $\{\backslash \operatorname{text}\{s\} \backslash \text { eft(F\right) }\}_{-}\left\{t-\{\mid \mathrm{ag}\}_{-}\{\backslash \mathrm{mu}\}\right\}$ generates smoother ${ }^{73}$ as explained for equation (4a), and $\mathrm{f} \backslash$ left(T $\backslash$ right) parameterizes the weighted effects of mean winter temperature (December-February) on mussel biomasses two and three years later. The $\{l a g\}_{-}\{\backslash \mathrm{mu}\}$ can have values 1, 2 or 3 (cf. equation (4a)). Biomass estimates $\{\backslash m u\}_{-}\{\backslash$ left $(t, j=2 \backslash$ right $)\}$ for SchleswigHolstein follows the parameterization given in equation (5), excepting an independent demographic error term $\{\backslash$ delta $\} \_\{\backslash m u \backslash \text { left(t,2\right) }\}$ and additive scaling parameter for an observation model (Supplementary Methods).

A logit model for flesh proportion in mussels $\{f\}_{-}\{\backslash$ left(t\\right) $\}$ for the period 1998-2013 was expressed as:

$\{\text { begin }\{\text { array }\}\{c\} \text { logit } \backslash \text { end }\{\text { array }\} f\}_{-}\{\backslash$ left $(t \backslash r i g h t)\}=\{a\}_{-}\{f\}+\{\backslash \text { sum }\}_{-}\{k=1\}^{\wedge}\{2\}\{b\}_{-}\{T, k\}\{T\}_{-}\{k \backslash \text { eft }(t \backslash r i g h t)\}_{+}$

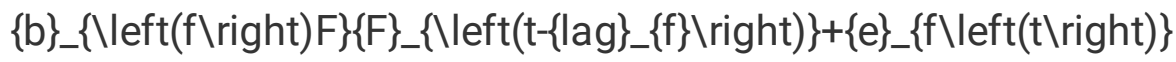

6

in which the flesh proportion is predicted with parameters $\{b\}_{-}\{T, k\}$ for winter $\{T\}_{-}\{k=1 \backslash$ left(t $\backslash$ right $\left.)\right\}$ and spring $\{T\}_{-}\{k=2 \backslash$ left(t\right) $\}$ temperatures, and $\{b\}_{-}\{\backslash$ left(f $\backslash$ right $\left.) F\right\}$ for lagged fertilizer use $\{F\}_{-}\{\backslash$ left(t- 


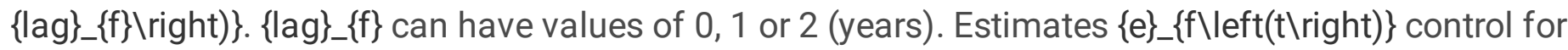
random disturbances on flesh proportions (Supplementary Methods).

\section{Results}

The output of the hierarchical Bayesian state-space models in long-tailed ducks and lemmings, as well as generalized linear models for juvenile proportions in long-tailed ducks and nutrients (DIN and DIP), are reported in Supplementary Tables S1a-c and S2, and Figures 2-4 visualize estimated dynamical trends and relations between model variables. Figure 5 summarizes the directions and strengths of variable effects and causalities between lemmings and long-tailed duck juvenile proportions, and spring migration counts $\{\mathrm{n}\}_{-}\{(\backslash \mathrm{left}(\mathrm{t} \backslash$ right $)\}$ as estimated with equations (1) - (3). For most parameters, Bayesian probability, $p$-value (or degree of belief, $c f$. statistical significance) was high implying that the probability for a parameter coefficient being smaller or, respectively, larger than zero converged close to one.

The magnitude of lemming population peaks in the western Taimyr Peninsula have declined over time (Fig. 2) and the 3-year cyclic regularity was broken after 1994 (Supplementary Table S1a, Supplementary Methods). Equation (3) shows that lemming populations declined with increasing autumn precipitation in the previous year and increased weakly when early summer precipitation was high (Supplementary Table S1a). The autumn precipitation affected particularly the Kara Sea population. The estimates for climate effects were highly convincing, with climate variation explaining $29 \%$ of the total lemming population variance. Of these climate variables, autumn precipitation had the stronger effect, explaining $84 \%$ of the lemming population variation due to climate (Supplementary Table S1a).

Colder and wetter springs and summers in North-western Taimyr led to fewer long-tailed duck recruits on the wintering grounds in the Baltic. This effect was stronger for variation in precipitation (Fig. 3a) than temperature (Fig. 3b) and was the strongest for May precipitation. Together the North-west Siberian climate variables explained $26 \%$ of the total variation in juvenile proportions. The proportion of juveniles declined the year following lemming peaks (Fig. 3c), implying that lemming population troughs that followed abundance peaks were poor years for long-tailed duck recruitment. Lemming population variation explained $9 \%$ of juvenile proportions (Supplementary Table S1b). High NAOI was followed by declines in juvenile proportion with a three-year lag (Fig. 3d), suggesting poor recruitment three years after a warm winter. Together, the climate parameters (Fig. 3) explained 39\% of the total variance estimated for the long-tailed duck juvenile proportion (Supplementary Table S1b).

Long-tailed duck spring migration counts as estimated with equation (1) increased with increasing DIN and decreasing DIP in the southern Baltic Sea in the previous year (24\% variance partition proportion for the joint effect with high statistical confidence, Supplementary Table S1c). The weighting parameter $\{w\}_{-}\{D\}(=0.49)$ for the combined effect of nutrients in the southern Baltic Sea suggested similar effect sizes for DIN and DIP. Figure 4a shows the joint effect. Increases in juvenile proportions in autumn and winter, i.e. $\{\mathrm{R}\}_{-}\{\backslash$ left(t\right)\} from equation (2), were followed by slight increases in numbers of springmigrating long-tailed ducks $\{\mathrm{n}\} \_\{\text {left(t+1 } \mathrm{t} \backslash \text { right) }\}$ from equation (1) (5\% variance partition proportion, Supplementary Table S1c), which is best illustrated by plotting annual population growth rates, 


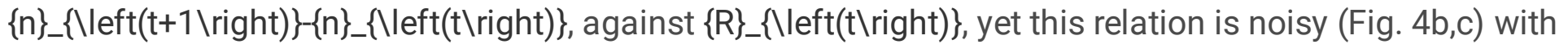
parameter distribution skewed to right: $P\left(\{\backslash \text { beta }\}_{-}\{R\}>0.05\right)=0.9$ (mean of $\{\text { beta }\}_{-}\{R\}=0.25 \pm 0.17 S D$ ). Density-dependent population regulation of the long-tailed duck was observed (22\% variance partition proportion).

The observation process variation (i.e., sampling error or observation error) of spring migration counts was affected by east-west aspect winds such that observed counts decreased with strengthening west winds during the annual census period. The details of wind effects on the observations, which delineated the performance of the population model given in equation (1), are reported in Supplementary Methods. After correcting for measurement errors, number of spring migrant long-tailed ducks showed relatively smooth annual variation and increased from the end of the 1960s up to 1991 followed by a steep decline from 1992 until the end of the 2000s. Some recovery took place in the beginning of the 2010s (Fig. 4d). The whole system modelled for and around the long-tailed duck is summarized in Fig. 5.

Application of more fertilizer to Danish farmland led to higher DIN and DIP in the southern Baltic Sea the following year. This 1-year lagged effect $($ lag $=1)$ was returned from $94.25 \%$ of the simulation updates (Supplementary Table S2).

High winter temperature was followed by lower mussel stocks in the Wadden Sea 2-3 years later (more weight for 2-year lag). Mussel biomass increased with the increasing use of fertilizers (Fig. 6a) in previous years, most strongly 1-2 years before. Simulation chains revealed frequencies for the lags of 0 , 1,2 , and 3 years of $6.3,31.0,43.4$, and 19.3 percent, respectively. Fertilizer and the smoother based on the spline function dominated the estimated variance for mussel biomass (Supplementary Table S3a). More demographic variance caused by local disturbances affecting mussel dynamics was found for the population in the Danish than the Schleswig-Holstein part of the Wadden Sea (Supplementary Table S3a). Population trends were not perfectly parallel in the two areas (Fig. 6b). Together, mussel biomasses showed large variation during the period 1986-1998, entering steep decline from the turn of the 1990s and recovering from 2011 up to 2017 (Fig. 6b). The quality of blue mussels in autumn in terms of (log) flesh/shell ratio of the total biomass, i.e. \{\begin\{array\}\{c\}logit \end\{array\}f\}_\{p } \backslash \text { left(t\right)\} from equation } (6), increased with the previous winter's temperature (19\% variance partition proportion, Supplementary Table S3b) and fertiliser use over the two previous years (42\% variance partition proportion, Supplementary Table S3b, Fig. 7a, b) but spring temperatures had no effect on mussel quality. These results suggest that mussels in the Wadden Sea were in better condition, as measured in autumn, during the years of high nutrient availability and after warm winters. The system modelled for the blue mussel flesh/shell ratio and biomass is summarized in Fig. 8 .

\section{Discussion}

This integrated hierarchical model for the long-tailed duck population investigates a complex stochastic system affected dynamically by sub-systems that are also stochastic and regulated by independent variables ${ }^{71,76}$. This model allowed us first, to correct for population estimate errors due to variation in 
wind velocity and direction at Söderskär, Gulf of Finland, during spring migration, which accounted for $51 \%$ of the total observation error variance. This result underlines that ignoring wind effects on counts would have led to serious misspecifications in the state-space model for long-tailed ducks.

This model allowed us to identify and quantify the variables contributing to population size variation of the long-tailed duck by using sub-models for trophic processes driven by nutrient and climate factors occurring at both the breeding and the wintering grounds. We were able to attribute $51 \%$ of total variation in long-tailed duck population size, estimated from spring migration counts, to ecological processes occurring at the breeding or overwintering grounds (Fig. 5). The processes that influence long-tailed duck populations in these two habitats are driven by different ecological interactions, for example predatordriven on the breeding grounds $26,77,78$ and resource-driven on the wintering grounds $44,64,65,79$ with very different climatic and environmental controls, for example, precipitation that influences lemming dynamics on the breeding grounds and temperature and nutrient runoff from the land that affect mussel reproduction, growth and survival on the wintering grounds.

On the breeding grounds, lemming population cycles affected the number of new recruits of long-tailed ducks, estimated from the proportion of juvenile birds killed by hunters in the winter. The year following high lemming years have few recruits while those following low lemming years show many (Fig. 3c). This is expected if predator numbers are high the year after a lemming peak and these predators switch to eggs and nestlings if lemmings are rare ${ }^{11,26,80}$. Western Taimyr lemming dynamics was driven by climate, particularly autumn and winter precipitation ${ }^{37}$ (Fig. 5). High autumn precipitation was associated with low lemming population size the next year. Heavy autumn precipitation may cause ice formation at the soil surface in the subnivean space, reducing the insulation properties of snow ${ }^{38,39}$, which leads to poor lemming winter success ${ }^{18,37,81-83}$.

High late spring and early summer precipitation with low temperatures in North-western Siberia were directly related to decreases in juvenile proportions in long-tailed ducks (Fig. 5). This may be linked to varying nesting areas and predation pressure during snow melt: more precipitation during cold springs delays snow melt ${ }^{84,85}$, which limits open areas for nesting and thus enhances predation on birds' nests during early breeding season ${ }^{85}$.

Recruitment, as estimated from juvenile proportion of hunters' returns, though it is the raw material of population growth and renewal, explained $5 \%$ of variation in spring migration numbers. This is unremarkable for a long-lived species like the long-tailed duck ${ }^{86}$, where adult survival drives population dynamics more than does fecundity ${ }^{87-90}$. Furthermore, juvenile proportion of hunters' returns is probably representative of the population. Long-tailed duck juveniles resemble mature females in autumn and winter so hunting pressure is unlikely to be age dependent, as for some other quarry species ${ }^{91}$.

On the wintering grounds long-tailed ducks are feeding mainly on blue mussels ${ }^{42,43,70}$. Mussels reproduce more during cold than warm winters ${ }^{44,70}$. NAOI values that represent variation in winter temperatures showed the strongest association with juvenile long-tailed duck proportion at the wintering 
grounds in the southern Baltic Sea three years later. If mussels require two or three years to reach the preferred size for long-tailed duck food items ${ }^{43,66}$, then food on the wintering grounds will be scarce two or three years after a warm winter but abundant two or three years after a cold winter. In the Wadden Sea the best fitting lag between cold winters and mussel biomass increase was two years (Fig. 8). Years of high food abundance on the wintering grounds should enhance female condition, increasing their fecundity and maternal investment ${ }^{44,64}$. Thus we would expect, as we find, higher nesting and fledging success three years after cold winters.

We detected effects of fertilizer runoff on long-tailed duck populations via the trophic cascade primed by dissolved nutrients ${ }^{46}$. Long-tailed duck populations increased with increasing DIN that translated into increased biomass and quality of mussels. However, the opposite trend was observed for DIP because increased DIP led to larger and more long-lasting hypoxia and bottom death $45,46,92$. Similar results that are supported by related studies of eiders and other waterbirds 44,79 .

Here we estimated the effects of dissolved nutrients, in the form of nutrient load from Danish farmland, on mussel biomass data from the Wadden Sea. Though we have argued that these predictions about how DIN influences food supply for long-tailed ducks are likely to be appropriate, data from the Wadden Sea on the effects of DIP cannot be directly generalized to the Baltic Sea, which, unlike the Wadden Sea, experiences hypoxia due to nutrient overload $45,46,92$. Hypoxia in the Baltic Sea has resulted in the elimination of benthic fauna over large areas and has severely disrupted food webs ${ }^{79,93-96}$ with expectable adverse effects on sea birds $6,79,97,98$. It is known that hypoxia increases with increasing DIP in the Baltic Sea 46,92 , thus according to the expectation we find that long-tailed ducks declined with increasing DIP.

In conclusion, we used hierarchical Bayesian models to quantify the effects of population and observation processes on the estimation of the abundance of the long-tailed duck, an Arctic migratory bird. This approach allowed us to estimate the amount of variance accounted for by environmental conditions both the breeding and wintering grounds. At the Arctic breeding ground, predation limits nesting success when lemming predators shift to alternative prey such as the long-tailed duck. In the marine winter quarters fertilizer runoff from agriculture drives a bottom-up trophic cascade, stimulating food availability by increasing primary production and thereby mussel biomass and quality. However, phosphorus overload could limit food availability by inducing hypoxia and bottom death. These conditions at the wintering grounds affect juvenile survival and adult female body condition before spring migration to the Arctic breeding grounds. The originality of this study resides in our ability to quantify the effects at both breeding and wintering areas that present very different ecological and environmental conditions and challenges. This approach should be useful for analysing the dynamics of other migratory species confronted with divergent environmental conditions in winter and summer habitats.

\section{Declarations}




\section{Data availability}

The data supporting the results of this study are provided as Supplementary Data ( $\mathrm{R}$ workspace list-type objects printed as "data_*.docx" and "inits_*.docx" files) referenced in the Bayesian analyses (section "Program codes" in Supplementary Methods).

\section{Acknowledgments}

In Söderskär the following persons, whom we thank sincerely, have conducted Arctic migration censuses, and offered data for research: Esa Nikunen, Markku Nygård, Olli Paavilainen, Pekka Pamilo, Martti Santakari and Karl Selin. Several tens of other bird observers contributed to migration counts and the list of names is too long to mention here. Roland Vösa digitized the wind data from the original notebooks from Söderskär observatory. Also thank to Jakob Strand for data of mussel flesh content collected during 1998-2013, and Thomas Kjær Christensen for data of the Danish wing survey. We sincerely thank Jacqui Shykoff for providing suggestions, comments and editorial help on the final version of the manuscript.

\section{Founding}

The work has been supported by The 15. June Foundation, Denmark (Ref.

2019-J-3) received by KL (http:/ww.15junifonden.dk/).

\section{Author contributions}

J.R. processed the data, performed the statistical analysis, and wrote the manuscript. M.H. performed fieldwork and processed the data. K.L. and A.P.M. wrote the manuscript. All authors reviewed the manuscript critically. All authors approved the final manuscript.

\section{Additional information}

The authors declare no competing interests. Supplementary Information: The online version contains supplementary material: Supplementary Methods, Supplementary Tables and Supplementary Data.

\section{References}

1. Berthold, P. Bird Migration: A General Survey. (Oxford University Press, 2001).

2. Harrison, X. A., Blount, J. D., Inger, R., Norris, D. R. \& Bearhop, S. Carry-over effects as drivers of fitness differences in animals. J. Anim. Ecol. 80, 4-18 (2011).

3. Webster, M. S., Marra, P. P., Haig, S. M., Bensch, S. \& Holmes, R. T. Links between worlds: Unraveling migratory connectivity. Trends Ecol. Evol. 17, 76-83 (2002).

4. Saurola, P., Valkama, J. \& Velmala, W. Suomen rengastusatlas Osa I/ The Finnish Bird Ringing Atlas Vol. I. (Finnish Museum of Natural History and Ministry of Environment, 2013). 
5. Bergman, G. Allin ja mustalinnun muuttokannat keväällä 1960 (in Finnish). Suomen Riista 14, 69-74 (1961).

6. Skov, H. et al. Waterbird Populations and Pressures in the Baltic Sea. (TemaNord 550, 2011).

7. Grenquist, P. Öljytuhoista Suomen aluevesillä v. 1948-1955. Suomen Riista 10, 105-116 (1956).

8. Hario, M., Rintala, J. \& Nordenswan, G. Dynamics of wintering long-tailed ducks in the Baltic Sea the connection with lemming cycles, oil disasters, and hunting. Suomen Riista 55, 83-96 (2009).

9. Ellermaa, M. \& Pettay, T. Põõsaspean niemen arktinen muutto syksyllä 2004. Linnut Vuosik. 2005, 99-112 (2005).

10. Delany, S. \& Scott, D. Waterbird Population Estimates. (Wetlands International, 2006).

11. Gauthier, G., Bëty, J., Giroux, J.-F. \& Rochefort, L. Trophic interactions in a high arctic snow goose colony. Integr. Comp. Biol. 44, 119-129 (2004).

12. Elton, C. Voles, Mice and Lemmings: Problems in Population Dynamics. (Clarendon Press, 1942).

13. Ehrich, D. et al. Documenting lemming population change in the Arctic: Can we detect trends? Ambio 786-800 (2019).

14. Kokorev, Y. I. \& Kuksov, V. A. Population dynamics of lemmings, Lemmus sibirica and Dicrostonyx torquatus, and Arctic Fox Alopex lagopus on the Taimyr peninsula, Siberia, 1960-2001. Ornis Svecica 12, 139-145 (2002).

15. Nolet, B. a et al. Faltering lemming cycles reduce productivity and population size of a migratory Arctic goose species. J. Anim. Ecol. 82, 804-13 (2013).

16. Angerbjörn, A., Tannerfeldt, M. \& Erlinge, S. Predator-prey relationships: Arctic foxes and lemmings. J. Anim. Ecol. 68, 34-49 (1999).

17. Fauteux, D., Gauthier, G. \& Berteaux, D. Seasonal demography of a cyclic lemming population in the Canadian Arctic. J. Anim. Ecol. 84, 1412-1422 (2015).

18. Gilg, O., Sittler, B. \& Hanski, I. Climate change and cyclic predator-prey population dynamics in the high Arctic. Glob. Chang. Biol. 15, 2634-2652 (2009).

19. Berryman, A. A. The orgins and evolution of predator-prey theory. Ecology 73, 1530-1535 (1992).

20. Framstad, E., Stenseth, N. C., Bjørnstad, O. N. \& Falck, W. Limit cycles in Norwegian lemmings: tensions between phase-dependence and density-dependence. Proc. R. Soc. London. Ser. B Biol. Sci. 264, 31-38 (1997).

21. Hanski, I. \& Korpimaki, E. Microtine rodent dynamics in northern Europe: Parameterized models for the predator-prey interaction. Ecology 76, 840-850 (1995).

22. May, R. M. Limit cycles in predator-prey communities. Science 177, 900-902 (1972).

23. Gilg, O., Hanski, I. \& Sittler, B. Cyclic dynamics in a simple vertebrate predator-prey community. Science 302, 866-868 (2003).

24. Juhasz, C. C., Shipley, B., Gauthier, G., Berteaux, D. \& Lecomte, N. Direct and indirect effects of regional and local climatic factors on trophic interactions in the Arctic tundra. J. Anim. Ecol. 89, 704715 (2020). 
25. McKinnon, L., Berteaux, D., Gauthier, G. \& Bêty, J. Predator-mediated interactions between preferred, alternative and incidental prey in the arctic tundra. Oikos 122, 1042-1048 (2013).

26. Sokolov, V., Vardeh, S. \& Quillfeldt, P. Long-tailed Duck (Clangula hyemalis) ecology: insights from the Russian literature. Part 1: Asian part of the Russian breeding range. Polar Biol. 42, 2259-2276 (2019).

27. Summers, R. W. \& Underhill, L. G. Factors related to breeding production of Brent Geese Branta $b$. bernicla and waders (Charadrii) onthe Taimyr Peninsula. Bird Study 34, 161:171 (1987).

28. Underhill, L. G. et al. Breeding of waders (Charadrii) and Brent Geese Branta bernicla bernicla at Pronchishcheva Lake, northeastern Taimyr, Russia, in a peak and a decreasing lemming year. Ibis 135, 277-292 (1993).

29. Angelstam, P., Lindström, E. \& Widén, P. Role of predation in short-term population fluctuations of some birds and mammals in Fennoscandia. Oecologia 62, 199-208 (1984).

30. Ehrich, D. et al. Vole abundance and reindeer carcasses determine breeding activity of Arctic foxes in Iow Arctic Yamal, Russia. BMC Ecol. 17, 1-13 (2017).

31. Brook, R. W., Duncan, D. C., Hines, J. E., Carrière, S. \& Clark, R. G. Effects of small mammal cycles on productivity of boreal ducks. Wildlife Biol. 11, 3-11 (2005).

32. Guillemain, M. et al. Effects of climate change on European ducks: what do we know and what do we need to know? Wildlife Biol. 19, 404-419 (2013).

33. Pehrsson, 0 . Duckling production of the Oldsquaw in relation to spring weather and small-rodent fluctuations. Can. J. Zool. 64, 1835-1841 (1986).

34. ACIA. Impacts of a Warming Arctic: Arctic Climate Impact Assessment. (Cambridge University Press, 2004).

35. Høye, T. T., Post, E., Meltofte, H., Schmidt, N. M. \& Forchhammer, M. C. Rapid advancement of spring in the High Arctic. Current Biology vol. 17 R449-R451 (2007).

36. Post, E. et al. Ecological dynamics across the arctic associated with recent climate change. Science $325,1355-1358$ (2009).

37. Kausrud, K. L. et al. Linking climate change to lemming cycles. Nature 456, 93-97 (2008).

38. Berteaux, D. et al. Effects of changing permafrost and snow conditions on tundra wildlife: critical places and times. Arct. Sci. 3, 65-90 (2017).

39. Bilodeau, F., Gauthier, G. \& Berteaux, D. The effect of snow cover on lemming population cycles in the Canadian High Arctic. Oecologia 172, 1007-1016 (2013).

40. Madsen, F. J. On the food habits of the diving ducks in Denmark. Danish Rev. Game Biol. 3, 2-83 (1954).

41. Nilsson, L. Habitat selection, food choice, and feeding habits of diving ducks in coastal waters of South Sweden during the non-breeding season. Ornis Scand. 3, 55-78 (1972).

42. Žydelis, R. \& Ruškytè, D. Winter foraging of long-tailed ducks (Clangula hyemalis) exploiting different benthic communities in the Baltic Sea. Wilson Bull. 117, 133-141 (2005). 
43. Skabeikis, A. et al. Effect of round goby (Neogobius melanostomus) invasion on blue mussel (Mytilus edulis trossulus) population and winter diet of the long-tailed duck (Clangula hyemalis). Biol. Invasions 21, 911-923 (2019).

44. Laursen, K. \& Møller, A. P. Long-Term changes in nutrients and mussel stocks are related to numbers of breeding eiders Somateria mollissima at a large Baltic colony. PLoS One 9, e95851 (2014).

45. Carstensen, J., Andersen, J. H., Gustafsson, B. G. \& Conley, D. J. Deoxygenation of the baltic sea during the last century. Proc. Natl. Acad. Sci. U. S. A. 111, 5628-5633 (2014).

46. Savchuk, O. P. Large-scale nutrient dynamics in the Baltic Sea, 1970-2016. Front. Mar. Sci. 5, 95 (2018).

47. Møller, A. P., Flensted-Jensen, E. \& Mardal, W. Agriculture, fertilizers and life history of a coastal seabird. J. Anim. Ecol. 76, 515-25 (2007).

48. Møller, A. P., Thorup, O. \& Laursen, K. Predation and nutrients drive population declines in breeding waders. Ecol. Appl. 28, 1292-1301 (2018).

49. Gelman, A., Carlin, J. B., Stern, H. S. \& Rubin, D. B. Bayesian Data Analysis. (Chapman \& Hall/CRC, 2004).

50. Lebreton, J.-D. \& Gimenez, O. Detecting and estimating density dependence in wildlife populations. J. Wildl. Manage. 77, 12-23 (2013).

51. Bergman, G. The spring migration of the Long-tailed Duck and the Common Scoter in western Finland. Ornis Fenn. 51, 129-145 (1974).

52. Richardson, W. J. Timing and amount of bird migration in relation to weather: A Review. Oikos 30, 224-272 (1978).

53. Alerstam, T. Bird flight and optimal migration. Trends Ecol. Evol. 6, 210-215 (1991).

54. Richardson, W. J. Wind and Orientation of Migrating Birds: A Review. in Orientation in Birds (ed. Berthold, P.) 226-249 (Birkhäuser, 1991). doi:10.1007/978-3-0348-7208-9_11.

55. Christensen, T. K. \& Fox, A. D. Changes in age and sex ratios amongst samples of hunter-shot wings from common duck species in Denmark 1982-2010. Eur. J. Wildl. Res. 60, 303-312 (2014).

56. Fox, A. D., Clausen, K. K., Dalby, L., Christensen, T. K. \& Sunde, P. Age-ratio bias among hunter-based surveys of Eurasian Wigeon Anas penelope based on wing vs. field samples. Ibis 157, 391-395 (2015).

57. Scott, D. A. \& Rose, P. M. Atlas of Anatidae Populations in Africa and Western Eurasia. Wetlands International Publication 41 (Wetlands International, 1996).

58. Fick, S. E. \& Hijmans, R. J. WorldClim 2: new 1-km spatial resolution climate surfaces for global land areas. Int. J. Climatol. 37, 4302-4315 (2017).

59. Harris, I., Jones, P. D., Osborn, T. J. \& Lister, D. H. Updated high-resolution grids of monthly climatic observations - the CRU TS3.10 Dataset. Int. J. Climatol. 34, 623-642 (2014).

60. Hijmans, R. J. Introduction to the 'raster' package (version 3.0-12). https://rspatial.org/raster/pkg/index.html (2020). 
61. Hurrell, J. W. Decadal trends in the north atlantic oscillation: regional temperatures and precipitation. Science vol. 269 676-679 (1995).

62. National Center for Atmospheric Research Staff. The Climate Data Guide: Hurrell North Atlantic Oscillation (NAO) Index (PC-based). https://climatedataguide.ucar.edu/climate-data/hurrell-northatlantic-oscillation-nao-index-pc-based (2019).

63. Nehls, G. et al. Beds of blue mussels and Pacific oysters. Quality Status Report, Thematic Report; No. 11. Wadden Sea Ecosystem; No. 25 (2009).

64. Laursen, K., Møller, A. P., Haugaard, L., Öst, M. \& Vainio, J. Allocation of body reserves during winter in eider Somateria mollissima as preparation for spring migration and reproduction. J. Sea Res. 144, 49-56 (2019).

65. Morelli, F., Laursen, K., Svitok, M., Benedetti, Y. \& Møller, A. P. Eiders, nutrients and eagles: Bottom-up and top-down population dynamics in a marine bird. J. Anim. Ecol. 1-10 (2021) doi:10.1111/13652656.13498.

66. Westerbom, M., Kilpi, M. \& Mustonen, O. Blue mussels, Mytilus edulis, at the edge of the range: population structure, growth and biomass along a salinity gradient in the north-eastern Baltic Sea. Mar. Biol. 140, 991-999 (2002).

67. Büttger, H., Nehls, G. \& Stoddard, P. The history of intertidal blue mussel beds in the North Frisian Wadden Sea in the 20th century: Can we define reference conditions for conservation targets by analysing aerial photographs? J. Sea Res. 87, 91-102 (2014).

68. Kristensen, P. S. \& Borgstrøm, R. The Danish Wadden Sea: fishery of mussels (Mytilus edulis L.) in a wildlife reserve? in Proceedings from the 11. Scientific Wadden Sea Symposium, Esbjerg, Denmark, 4.-8. April 2005. NERI technical report (ed. Laursen, K.) vol. 573 107-111 (National Environmental Research Institute. Department of Wildlife Ecology and Biodiversity, 2006).

69. Baird, R. H. Measurement of condition in mussels and oysters. ICES J. Mar. Sci. 23, 249-257 (1958).

70. Waldeck, P. \& Larsson, K. Effects of winter water temperature on mass loss in Baltic blue mussels: Implications for foraging sea ducks. J. Exp. Mar. Bio. Ecol. 444, 24-30 (2013).

71. Kery, M. \& Schaub, M. Bayesian Population Analysis Using WinBUGS: A Hierarchical Perspective. (Elsevier, 2012).

72. Saha, K. \& Paul, S. Bias-corrected maximum likelihood estimator of the negative binomial dispersion parameter. Biometrics 61, 179-185 (2005).

73. Crainiceanu, C. M., Ruppert, D. \& Wand, M. P. Bayesian analysis for penalized spline regression using WinBUGS. J. Stat. Softw. 14, (2005).

74. Mutshinda, C. M., O'Hara, R. B. \& Woiwod, I. P. A multispecies perspective on ecological impacts of climatic forcing. J. Anim. Ecol. 80, 101-107 (2011).

75. Pöysä, H. et al. Environmental variability and population dynamics: do European and North American ducks play by the same rules? Ecol. Evol. 6, 7004-7014 (2016). 
76. Almaraz, P., Green, A. J., Aguilera, E., Rendón, M. a \& Bustamante, J. Estimating partial observability and nonlinear climate effects on stochastic community dynamics of migratory waterfowl. J. Anim. Ecol. (2012) doi:10.1111/j.1365-2656.2012.01972.x.

77. Schmidt, N. M. et al. Response of an arctic predator guild to collapsing lemming cycles. Proc. R. Soc. B Biol. Sci. 279, 4417-4422 (2012).

78. Summers, R. W., Underhill, L. G. \& Syroechkovski, J. The breeding productivity of dark-bellied brent geese and curlew sandpipers in relation to changes in the numbers of arctic foxes and lemmings on the Taimyr Peninsula, Siberia. Ecography 21, 573-580 (1998).

79. Møller, A. P., Flensted-Jensen, E., Laursen, K. \& Mardal, W. Fertilizer leakage to the marine environment, ecosystem effects and population trends of waterbirds in Denmark. Ecosystems 18, 30-44 (2015).

80. Ebbinge, B. S., Heesterbeek, H. J. A. P., Ens, B. J. \& Goedhart, P. W. Density dependent population limitation in dark-bellied brent geese Branta b. bernicla. Avian Sci. 2, 63-75 (2002).

81. Domine, F. et al. Snow physical properties may be a significant determinant of lemming population dynamics in the high Arctic. Arct. Sci. 4, 813-826 (2018).

82. Ims, R. A., Henden, J.-A. \& Killengreen, S. T. Collapsing population cycles. Trends Ecol. Evol. 23, 7986 (2008).

83. Korslund, L. \& Steen, H. Small rodent winter survival: Snow conditions limit access to food resources. J. Anim. Ecol. 75, 156-166 (2006).

84. Callaghan, T. V. et al. The changing face of arctic snow cover: A synthesis of observed and projected changes. Ambio 40, 17-31 (2011).

85. Machín, P. et al. The role of ecological and environmental conditions on the nesting success of waders in sub-Arctic Sweden. Polar Biol. 42, 1571-1579 (2019).

86. Koneff, M. D. et al. Evaluation of harvest and information needs for North American sea ducks. PLoS One 12, e0175411 (2017).

87. Benton, T. G. \& Grant, A. Elasticity analysis as an important tool in evolutionary and population ecology. Trends Ecol. Evol. 14, 467-471 (1999).

88. Heppell, S. S., Caswell, H. \& Crowder, L. B. Life histories and elasticity patterns: Perturbation analysis for species with minimal demographic data. Ecology 81, 654-665 (2000).

89. Sæther, B.-E. \& Bakke, O. Avian life history variation and contribution of demographic traits to the population growth rate. Ecology 81, 642-653 (2000).

90. Öst, M., Ramula, S., Lindén, A., Karell, P. \& Kilpi, M. Small-scale spatial and temporal variation in the demographic processes underlying the large-scale decline of eiders in the Baltic Sea. Popul. Ecol. 58, 121-133 (2016).

91. Holopainen, S. \& Fox, A. D. Associations between duck harvest, hunting wing ratios and measures of reproductive output in Northern Europe. Eur. J. Wildl. Res. 64, (2018). 
92. Conley, D. J., Humborg, C., Rahm, L., Savchuk, O. P. \& Wulff, F. Hypoxia in the Baltic Sea and basinscale changes in phosphorus biogeochemistry. Environ. Sci. Technol. 36, 5315-5320 (2002).

93. Carstensen, J. et al. Hypoxia in the Baltic Sea: Biogeochemical cycles, benthic fauna, and management. Ambio 43, 26-36 (2014).

94. Conley, D. J. et al. Hypoxia-related processes in the Baltic Sea. Environ. Sci. Technol. 43, 3412-3420 (2009).

95. Conley, D. J. et al. Long-term changes and impacts of hypoxia in Danish coastal waters. Ecol. Appl. 17, 165-184 (2007).

96. Diaz, R. J. \& Rosenberg, R. Spreading dead zones and consequences for marine ecosystems. Science 321, 926-929 (2008).

97. Fox, A. D. et al. Current and potential threats to Nordic duck populations - a horizon scanning exercise. Ann. Zool. Fennici 52, 193-220 (2015).

98. Møller, A. P. Biological consequences of global change for birds. Integr. Zool. 8, 136-144 (2013).

\section{Figures}

\section{Figure 1}

Study areas from the Wadden Sea, Denmark, and the Gulf of Finland extending to the Western Taimyr Peninsula, North-western Siberia, Russia. Colorations indicate regions for which map-based climatological variables were calculated. The coastal areas of the southern Baltic Sea form the main wintering area of long-tailed ducks breeding in North-western Siberia. The spring migration surveys were conducted at Söderskär. Mussels were surveyed on the Wadden Sea, and lemmings in the Western Taimyr Peninsula: Kara Sea, Meduza Bay, and Mys Vostochnyi. Map created using the free and open source QGIS (http://qgis.osgeo.org). Female long-tailed duck image by Antti Below. 


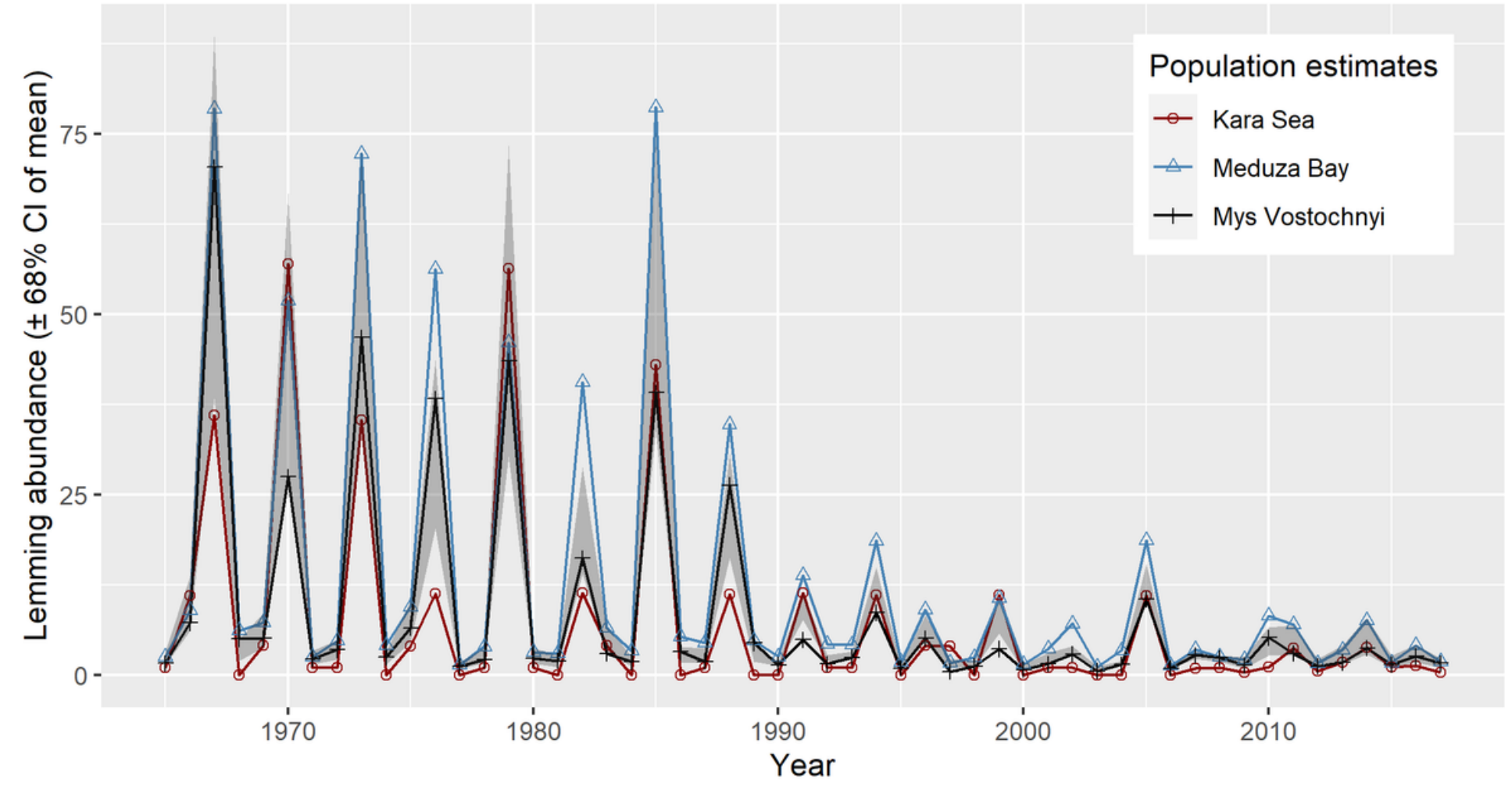

Figure 2

Dynamics of three lemming populations in the Western Taimyr Peninsula (population size estimates). Confidence interval $(\mathrm{Cl})$ is related to annual mean values based on the three lemming monitoring programs: Kara Sea, Meduza Bay, and Mys Vostochnyi.

\section{Figure 3}

Juvenile proportion of long-tailed ducks from Danish hunting returns in relation to North-western Siberian weather in May and June: (a) precipitation and (b) temperature, (c) estimated lemming abundance in the Western Taimyr Peninsula in the previous year, and (d) North Atlantic Oscillation Index (NAOI) three years before. Numbers indicate the year (1982-2017) of the observed data point and circles show the corresponding estimates based on equation (2). Triangles show estimates for the period 1967-1981 from which no observations were available. 

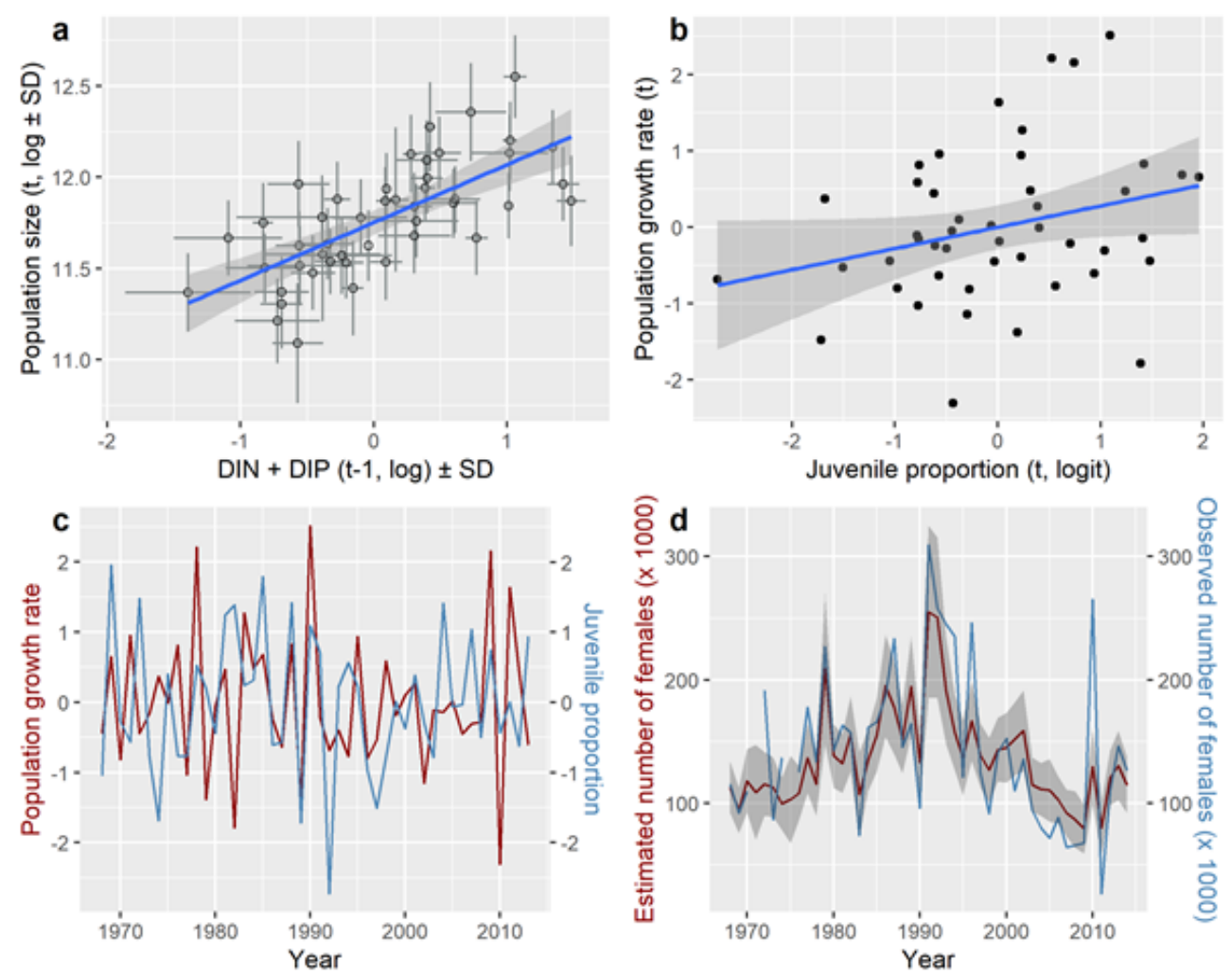

Fig. 4. (a) Joint effect of (weighted) DIN and DIP (dissolved nitrogen and phosphorus) in the previous year on long-tailed duck state population size from spring migration counts at Söderskär observatory. Nutrient amounts were measured in the southern Baltic Sea and their joint effect was calculated with the formulation $\left(1-w_{D}\right) D I N_{(t-1)}+$ $w_{D}\left(-1 * D I P_{(t-1)}\right)$ designed for estimation with equation (1). (b) The effect of juvenile proportions estimated using equation (2) based on wing data from Danish hunting returns on the population growth rate $(t)=n_{(t+1)}-n_{(t)}$ of long-tailed ducks estimated using equation (1) and (c) the trajectories of these during 1968-2013. Values are scaled to mean zero and unit variance. (d) Observed and predicted numbers of spring migrating female long-tailed ducks at Söderskär. Population estimates and confidence interval are calculated using a hierarchical state-space model as given in equation (1).

\section{Figure 4}

"See image above for figure legend" 


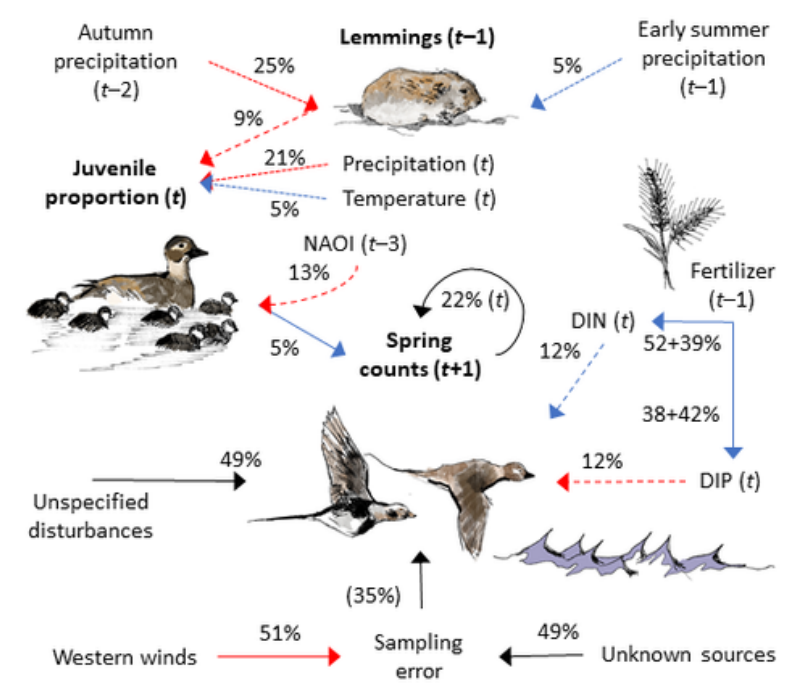

\section{Figure 5}

Summary of model parameters affecting long-tailed duck (LtD) Clangula hyemalis population size (Spring counts). Dissolved nitrogen (DIN) and phosphorus (DIP) in the southern Baltic Sea are affected by fertilizer use in the Danish farmland. Climate variables affect lemming Lemmus sibiricus and Dicrostonyx torquatus abundances and juvenile proportions of LtD. "Precipitation" and "Temperature" refer to Northwestern Siberia in June and July, and "NAOI" is the North Atlantic Oscillation Index. Precipitations in the Western Taimyr Peninsula affect lemmings. Red/blue arrows indicate a negative/positive effect. Solid lines indicate direct effects. Trophic cascades drive indirect effects from one trophic level to another (long dash lines). Mechanisms behind Siberian climate effects (short dash lines) on lemmings and juvenile proportions were out of the scope of this study and were not included in the general discussion. Black arrows denote random errors from unknown sources and circle arrow illustrates density dependence. Percentages for DIN and DIP describe direct fertilizer plus smoother effects based on the fertilizer series. Variance partition proportions (\%) shown for the predictors. The sampling error proportion of the total LtD system (including sampling error variance) is in parentheses. Long-tailed ducks (female and hatchlings, and male and female on the sea), lemming L. sibiricus, and fertilizer-use symbol (crop) drawings by Kati Rintala. 


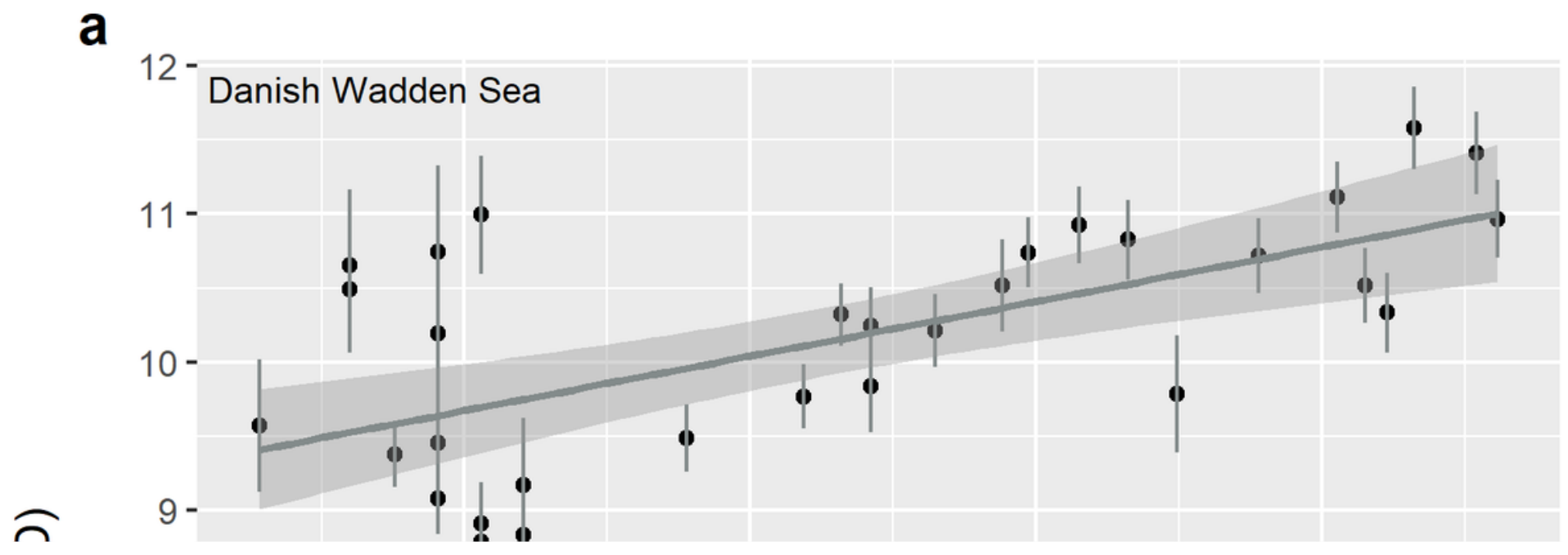

\section{Figure 6}

(a) Effect of fertilizer application to the Danish (DK) farmland on mussel biomass on the DK Wadden Sea two years later. (b) Estimated (lines) and observed (symbols) biomass trends of blue mussel populations in the DK and Schleswig-Holstein (SH) Wadden Sea in 1986-2017. 


\section{- Estimated - Obseved}

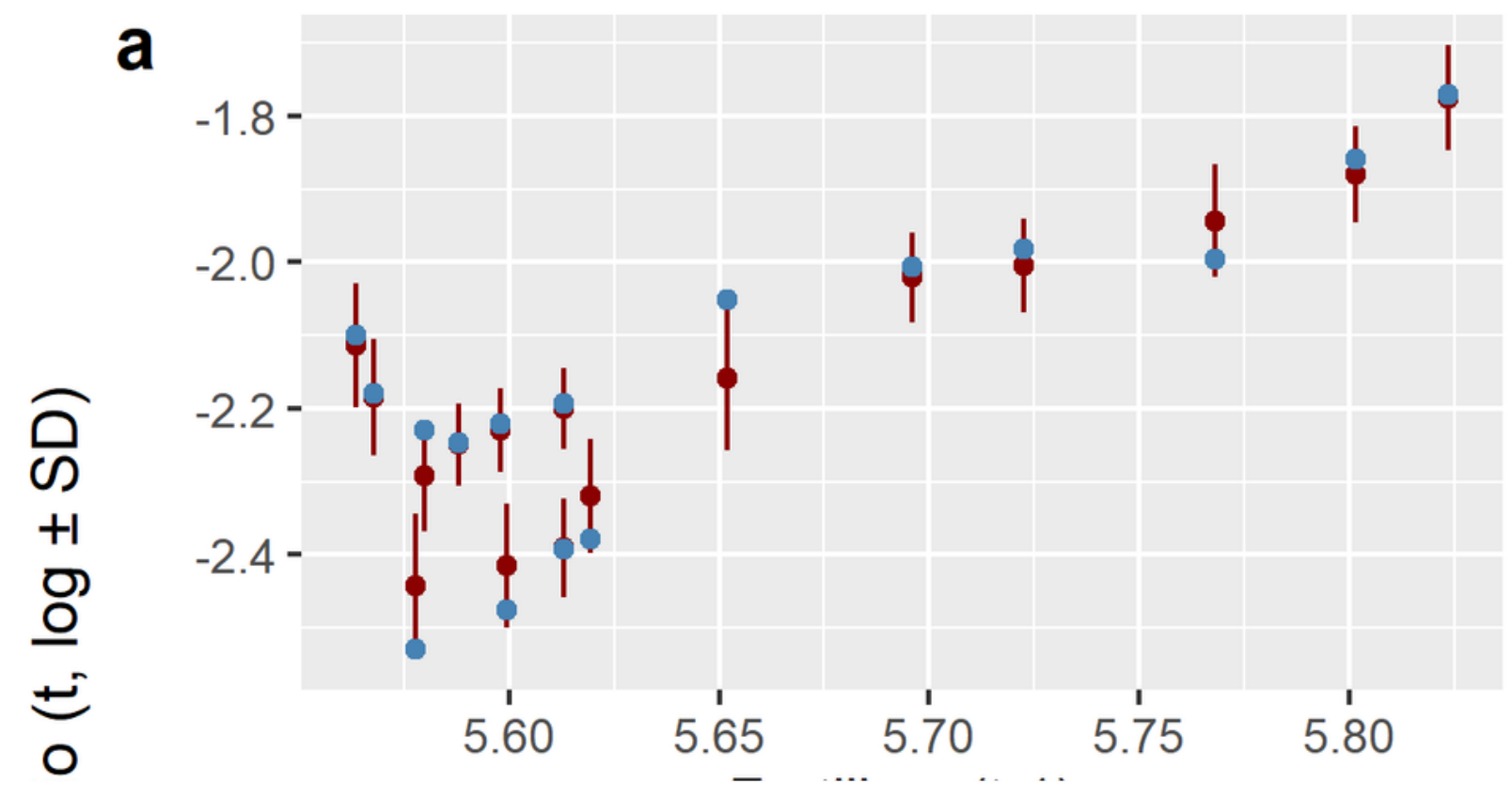

\section{Figure 7}

Predicted, estimated using equation (6) and observed mussel quality from samples from the Baltic and Wadden Sea, given as flesh/shell ratio, as a function of (a) Fertilizer application to Danish farmland in the previous year: In red, predictions with $68 \%$ confidence intervals. Observations from the Danish Wadden Sea are in blue. (b) Time in years from 1998-2013: The black line represents the predictions with $68 \%$ confidence limits in grey. 


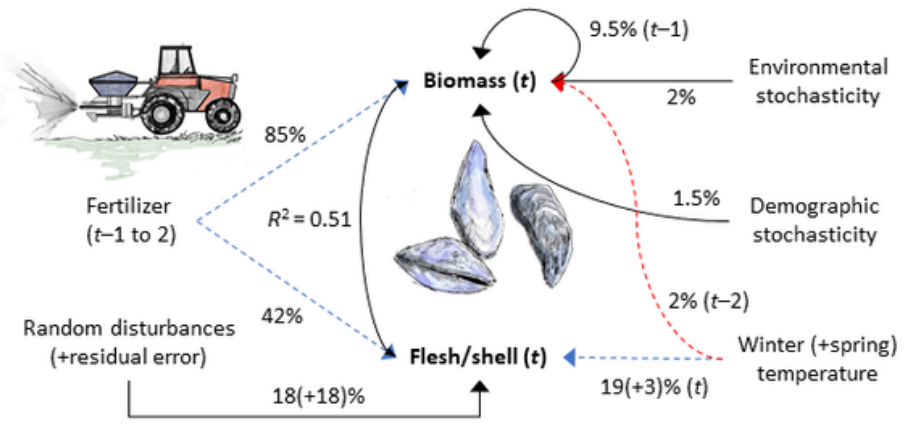

\section{Figure 8}

Summary of the models for the blue mussel Mytilus edulis biomasses in the Wadden Sea and flesh/shell ratios in the Wadden and Baltic Sea. Red/blue arrow indicates a negative/positive effect of a predictor on a response variable. Fertilizers are applied to Danish farmland while temperature refers to conditions on the Wadden Sea coastline. Dashed lines indicate indirect effects. Solid black arrows denote stochastic effects from unknown sources and circle arrow illustrates density dependence. Numbers represent the per cent of the total response variance explained by a predictor. $R^{2}$ comes from regressing log mussel biomass in the Wadden Sea against logit flesh proportion on data the from the Wadden and Baltic Sea (regression coefficient. 1.84, $F_{(1,14)}=14.4, P=0.002$ ). Blue mussels and fertilizer-spreading-tractor drawings by Kati Rintala.

\section{Supplementary Files}

This is a list of supplementary files associated with this preprint. Click to download.

- SupplementaryInformation.zip 